\title{
A Correlational Study on Taste Alterations and Quality of Life Among Cancer Patients
}

\author{
Darsana S. Wilson ${ }^{1} \quad$ Chitra C. Nair ${ }^{1} \quad$ Christy Johns $^{1} \quad$ Christy Mathew $^{1} \quad$ Dani Joseph $^{1} \quad$ Precilla DSilva $^{1}$ \\ ${ }^{1}$ Department of Obstetrics and Gynecological Nursing, Father \\ Muller College of Nursing, Mangaluru, Karnataka, India

\begin{abstract}
Address for correspondence Precilla DSilva, MSc, Department of Obstetrics and Gynecological Nursing, Father Muller College of Nursing, Father Muller Road, Dakshina Kannada, Mangaluru, Karnataka 575002, India (e-mail: precilladsilva25@fathermuller.in).
\end{abstract}

J Health Allied Sci NU 2021;11:147-153.

\begin{abstract}
Introduction One of the major problems faced by the world today is cancer. Cancer is an abnormal growth of cells. Chemotherapy, surgery, and radiation therapy are the treatment regimen for cancer. Prolonged use of chemotherapy drugs can cause different side effects such as alopecia, weight loss, sexual dysfunction, mood swings, and the most important one is taste alterations. The aim of the study is to determine the taste alterations (TAs) and quality of life (QOL) among cancer patients who have undergone three cycles of chemotherapy.

Methods The approach used is descriptive survey design. The sample comprised 62 cancer patients selected by convenient sampling. The tool used was baseline proforma, University of Washington Quality of Life (UW-QOL) questionnaire version 4.1, chemotherapy-induced taste alteration scale (CiTAS).

Results The majority of the patients belonged to the age group of 41 to 50 years (37.09\%) among whom $40 \%$ were females. The majority of the patients were not diagnosed with any other disease $(91.9 \%)$. Around $80.6 \%$ of patients reported to have sore mouth, out of whom $45.2 \%$ maintained oral care by brushing teeth. The most commonly seen type of tumor was head and neck (37.1\%) whereas the tumor type genitourinary was the least seen (3.2\%). The majority of the patients had stage II cancer (53.2\%) and about $62 \%$ of them did not have metastasis. There is significant association with selected demographic variables and QOL (sore mouth, oral care, and tumor type).

Keywords

- cancer patients

- QOL

- TAs There is also a significant association with selected demographic variable and TAs, (oral care and tumor type) and there is a negative correlation between TAs and QOL. Conclusion Identification of the severity of TA helps in providing alternative measures to improve the taste buds which may help in improving the QOL.
\end{abstract}

\section{Introduction}

One of the challenging conditions faced by the world today is cancer. Cancer is an abnormal growth of cells and it is also called malignancy. World health statistics from 2015 say

published online April 15, 2021
DOI https://doi.org/ $10.1055 / \mathrm{s}-0041-1726574$ ISSN 2582-4287 that cancer is the fifth leading cause of death. According to cancer statistics of India, in 2018 the number of people living with the disease was around 2.25 million per year and cancer-related death was around 7,84,821. ${ }^{1}$ The major cause of cancer is gene mutations which happen because of (c) 2021. Nitte (Deemed to be University).

This is an open access article published by Thieme under the terms of the Creative Commons Attribution-NonDerivative-NonCommercial-License, permitting copying and reproduction so long as the original work is given appropriate credit. Contents may not be used for commercial purposes, or adapted, remixed, transformed or built upon. (https://creativecommons.org/licenses/by-nc-nd/4.0/).

Thieme Medical and Scientific Publishers Pvt. Ltd. A-12, 2nd Floor, Sector 2, Noida-201301 UP, India 
smoking, radiation, viruses, cancer-causing chemicals, obesity, and so forth. The symptoms include fatigue, lump thickening, weight changes, skin changes, changes in the bowel or bladder patterns, and so forth. ${ }^{2}$

The treatment regimens for cancer are surgery, radiation therapy, and chemotherapy. Chemotherapy is the use of certain drugs or chemicals that inhibit the growth of cancer cells by destroying them and it often shortened to "chemo."3 Prolonged use of chemo drugs can cause different side effects such as alopecia, weight loss, sexual dysfunction, mood swings, and the most important one is taste alterations. Chemo drugs make changes in the receptors of mouth and alter the senses of taste. This may affect the weight of the patients by decreasing appetite and lead to disparity of the nutritional status of an individual. ${ }^{4}$

Cancer may also distract an individual's quality of life (QOL). According to World Health Organization, QOL is defined as "The individual's perception of their position in life in the context of the culture and value systems in which they live and in relation to their goals." In cancer patients QOL decreases due to the symptoms of cancer and the side effects of chemo drugs. It mainly disturbs the emotional balance of a person and may lead to anxiety and depression. The QOL of cancer patients can be improved by using different techniques such as complementary medicines, exercise, massage therapy, physical and occupational therapy, and so forth. ${ }^{5}$ Taste dysfunctions in patients impacts QOL and impairs oral intake, which may have broader implications consisting of weight loss and nutritional compromise.

Many research studies have shown that one of the factors contributing to QOL among cancer patients is taste alterations (TAs). Obtaining pleasure from food and the ability to maintain social eating habits may be impeded by food aversion and this may entail mood disturbances and decreased social functioning. ${ }^{6}$

The purpose of the study is thus to determine the TAs and QOL among cancer patients who have undergone three cycles of chemotherapy. Also an attempt is made to find out the correlation of QOL and taste alterations in cancer patients.

When the researchers were posted in oncology wards during their clinical posting they came across several patients complaining about TAs. Majority of the patients also verbalized their experiences with chemotherapy and its side effects, and how it is affecting their lifestyle. The researchers also searched databases such as PubMed, ResearchGate, and other journals that gave a thought to this statement. As the researchers were more interested in identifying the TAs and their relation to QOL, they decided to take up this study, and after finding the TAs, patients can be suggested to use alternative remedies to improve taste buds which may add to their QOL.

\section{Materials and Methods}

A descriptive research design was used for this study. Cancer patients between the age of 20 and 65 years who have completed more than three cycles of chemotherapy and who are visiting the outpatient department or day care unit, or those who are admitted in the selected Father Muller Medical College Hospital, Mangaluru, were selected as target population. A total of 62 patients were selected based on the convenient sampling. Sample size was calculated using following formula:

$$
\begin{gathered}
N=\frac{2\left(\mathrm{Z} \pm+\mathrm{Z}^{2}\right)^{2}}{C^{2}}+3 \quad N=\frac{2(1.96+0.80)^{2}}{0.559^{2}}+3 \\
\mathrm{C}=0.5 \times \ln [(1+\mathrm{r}) \div(1-\mathrm{r})] \mathrm{r}=0.51,
\end{gathered}
$$

where $N$ is the required sample size, $r$ is the obtained $r$ value from previous literature and $C$ is the obtained value using the mentioned formula.

Data collection instruments used were baseline proforma, University of Washington Quality of Life (UW-QOL) questionnaire version 4.1 (standardized tool and permission was obtained from the author), chemotherapy-induced taste alteration scale (CiTAS) (standardized tool and permission was obtained from the author). The tool was submitted to seven experts to establish the content validity. The reliability of the UW-QOL version 40.1 , which was translated in Kannada, was calculated by Karl Pearson's correlation coefficient and was found to be 0.95 , whereas the reliability of CiTAS was found to be 0.97 , which indicated that both the tools are reliable.

A formal written permission was obtained from the hospital authority. Data were collected from June 17, 2019, to July 8, 2019. Prior to data collection, the investigators familiarized themselves and confidentiality was maintained. An informed written consent was obtained from all the patients. Average time taken by each patient to complete the tool was approximately 25 to 30 minutes.

\section{Results}

A master data sheet was prepared and the coded data was entered. SPSS version 16 was used to analyze coded data. The study results were organized as follows:

- Table 1 shows that the majority of the patients belong to the age group of 41 to 50 years (37.09\%) among whom $40 \%$ are females. The majority of the patients are not diagnosed with any other disease (91.9\%). Around $80.6 \%$ of patients reported to have sore mouth, out of whom $45.2 \%$ maintained oral care by brushing teeth. The most commonly seen type of tumor was head and neck (37.1\%), whereas genitourinary tumor type was the least seen (3.2\%). Majority of the patients had stage II cancer (53.2\%) and $262 \%$ of them did not have metastasis.

\section{Mean and Standard Deviation of QOL}

The mean percentage obtained in - Table 2 indicates that majority of the cancer patients have good QOL ( $\mathbf{-}$ Tables 2- 5;

-Figs. 1 and 2 ).

Majority of the cancer patients experience mild to moderate type of TAs and that there is a correlation between TAs and QOL. This table also shows that the calculated $r$-value is -0.797 ( - Table 6). This suggests there is a strong negative 
Table 1 Frequency and percentage distribution of subjects according to their demographic variables

\begin{tabular}{|c|c|c|}
\hline \multicolumn{3}{|l|}{$n=62$} \\
\hline Variables & Frequency & $\%$ \\
\hline \multicolumn{3}{|l|}{ Age (mean age $49.87 \pm 9.82 \mathrm{y}$ ) } \\
\hline$\leq 30 \mathrm{y}$ & 2 & 3.2 \\
\hline $31-40 y$ & 9 & 14.5 \\
\hline $41-50 y$ & 23 & 37.09 \\
\hline $51-60 y$ & 20 & 32.2 \\
\hline $61-70 y$ & 8 & 12.9 \\
\hline \multicolumn{3}{|l|}{ Gender } \\
\hline Male & 22 & 35.5 \\
\hline Female & 40 & 64.5 \\
\hline \multicolumn{3}{|l|}{ Marital status } \\
\hline Single & 5 & 8.1 \\
\hline Married & 49 & 79.0 \\
\hline Divorced & 2 & 3.2 \\
\hline Widowed & 6 & 9.7 \\
\hline \multicolumn{3}{|l|}{ Diagnosed with another disease } \\
\hline Yes & 5 & 8.1 \\
\hline No & 57 & 91.9 \\
\hline \multicolumn{3}{|l|}{$\begin{array}{l}\text { Receiving drugs other than } \\
\text { chemotherapy }\end{array}$} \\
\hline Yes & 4 & 6.5 \\
\hline No & 58 & 93.5 \\
\hline \multicolumn{3}{|l|}{ Method of oral care } \\
\hline Brushing teeth & 28 & 45.2 \\
\hline Rinsing mouth with water & 13 & 21.0 \\
\hline Mouthwash & 15 & 24.2 \\
\hline Brushing teeth + mouthwash & 6 & 9.7 \\
\hline \multicolumn{3}{|l|}{ Presence of sore mouth } \\
\hline Yes & 12 & 19.4 \\
\hline No & 50 & 80.6 \\
\hline \multicolumn{3}{|l|}{ Tumor type } \\
\hline Head and neck & 23 & 37.1 \\
\hline Respiratory & 3 & 4.8 \\
\hline Gastrointestinal & 9 & 14.5 \\
\hline Reproductive & 19 & 30.6 \\
\hline Genitourinary & 2 & 3.2 \\
\hline Hematology & 6 & 9.7 \\
\hline \multicolumn{3}{|l|}{ Staging of cancer } \\
\hline I & 1 & 1.6 \\
\hline II & 33 & 53.2 \\
\hline III & 23 & 37.1 \\
\hline IV & 5 & 8.1 \\
\hline \multicolumn{3}{|l|}{ Presence of metastasis } \\
\hline Yes & 23 & 37.1 \\
\hline No & 39 & 62 \\
\hline
\end{tabular}

Table 2 Frequency and percentage distribution of quality of life (QOL) according to the grading

\begin{tabular}{|c|c|c|c|}
\hline \multicolumn{4}{|l|}{$n=62$} \\
\hline Grading QOL & Range & Frequency & $\%$ \\
\hline Poor & $0-465$ & 3 & 4.8 \\
\hline Good & $466-931$ & 28 & 45.2 \\
\hline Very good & $\geq 932$ & 31 & 50.0 \\
\hline
\end{tabular}

Note: Maximum score: 1,400 .

Table 3 Mean, mean percentage, and standard deviation (SD) of quality of life (QOL)

\begin{tabular}{|c|c|c|}
\hline \multicolumn{3}{|l|}{$n=62$} \\
\hline Variable & Mean \pm SD & Mean \% \\
\hline $\mathrm{QOL}$ & $905.83 \pm 266.53$ & 69.67 \\
\hline
\end{tabular}

Note: Maximum score: 1,400.

Table 4 Frequency and percentage distribution of taste alterations (TAs) according to the grading

\begin{tabular}{|l|l|l|l|}
\hline \multicolumn{5}{|l|}{$n=62$} & Frequency & $\%$ \\
\hline Grading TAs & Range & 32 & 51.6 \\
\hline Mild & $18-42$ & 10 & 16.1 \\
\hline Moderate & $43-67$ & 20 & 32.3 \\
\hline Severe & $4 \geq 68$ & 32 &
\end{tabular}

Note: Minimum score: 18; maximum score: 90.

Table 5 Mean, mean percentage, and standard deviation (SD) of taste alterations (TAs)

\begin{tabular}{|c|c|c|}
\hline \multicolumn{3}{|l|}{$n=62$} \\
\hline Variable & Mean \pm SD & Mean \% \\
\hline TAs & $47.98 \pm 23.49$ & 53.31 \\
\hline
\end{tabular}

Note: Minimum score: 18; maximum score: 90.

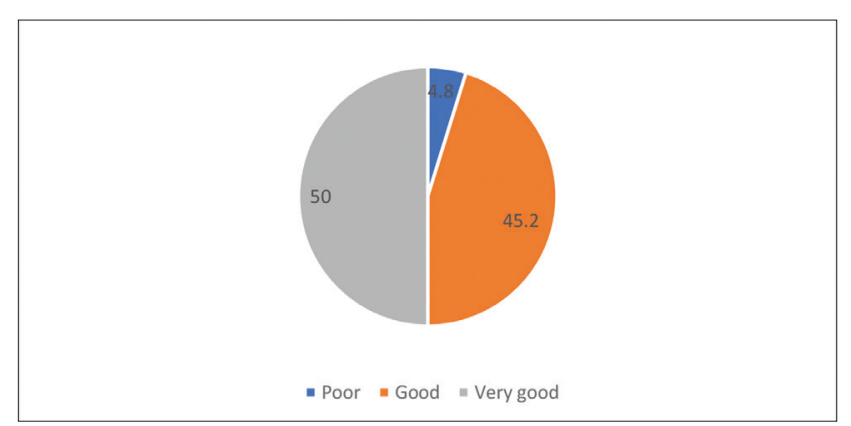

Fig. 1 Pie diagram showing grading of quality of life of cancer patients.

correlation with QOL and TAs and the $p$-value is 0.001 which is significant at 0.05 level of significance. Hence the null hypothesis is rejected and the research hypothesis is accepted (-Fig. 3).

Data presented in this table reveal that the $p$-value computed between the QOL and oral care $(p=0.001)$, 


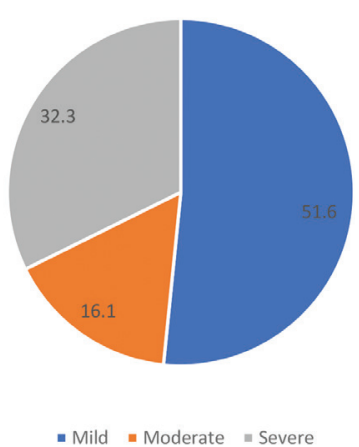

Fig. 2 Pie diagram showing grading of taste alterations of cancer patients.

Table 6 Correlation between quality of life (QOL) and taste alterations (TAs)

\begin{tabular}{|c|c|c|}
\hline \multicolumn{3}{|l|}{$n=62$} \\
\hline Variable & $r$-Value & $p$-Value \\
\hline QOL & -0.797 & 0.001 \\
\hline TAs & & \\
\hline
\end{tabular}

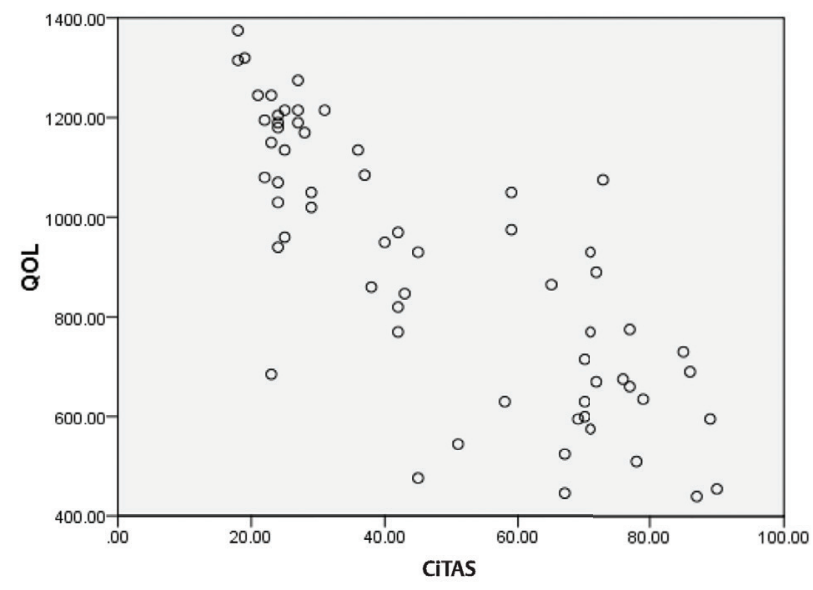

Fig. 3 Scatter plot showing correlation between taste alterations (TAs) and quality of life (QOL).

sore mouth ( $p=0.013)$, tumor type $(p=0.001)$ is $<0.05$ which is highly significant. Hence we accept the research hypothesis with regards to these three variables and conclude that there is significant association with selected demographic variables and QOL ( - Table 7).

Table 7 Association of quality of life (QOL) and demographic variables

\begin{tabular}{|c|c|c|c|c|c|c|}
\hline \multicolumn{7}{|l|}{$n=62$} \\
\hline \multirow[t]{2}{*}{ Variables } & \multicolumn{3}{|c|}{ Frequency } & \multirow[t]{2}{*}{$\chi^{2}$} & \multirow[t]{2}{*}{ df } & \multirow[t]{2}{*}{$p$-Value } \\
\hline & Poor & Good & Very good & & & \\
\hline \multicolumn{7}{|l|}{ Gender } \\
\hline Male & 2 & 10 & 10 & 1.416 & 2 & \\
\hline Female & 1 & 18 & 21 & \multicolumn{2}{|c|}{ (Fisher's exact) } & 0.574 \\
\hline \multicolumn{7}{|l|}{ Marital status } \\
\hline Single & 0 & 3 & 2 & 2.395 & 6 & \\
\hline Married & 3 & 20 & 26 & \multicolumn{2}{|c|}{ (Fisher's exact) } & 0.887 \\
\hline Divorced & 0 & 1 & 1 & & & \\
\hline Widowed & 0 & 4 & 2 & & & \\
\hline \multicolumn{7}{|l|}{ Diagnosed with another disease } \\
\hline Yes & 0 & 1 & 4 & 2.005 & 2 & \\
\hline No & 3 & 27 & 27 & \multicolumn{2}{|c|}{ (Fisher's exact) } & 0.502 \\
\hline \multicolumn{7}{|c|}{ Receiving drugs other than chemotherapy } \\
\hline Yes & 0 & 1 & 3 & 1.126 & 2 & \\
\hline No & 3 & 27 & 28 & \multicolumn{2}{|c|}{ (Fisher's exact) } & 0.685 \\
\hline \multicolumn{7}{|l|}{ Method of oral care } \\
\hline Brushing teeth & 0 & 6 & 22 & 20.824 & 6 & \\
\hline Rinsing mouth with water & 2 & 8 & 3 & \multicolumn{2}{|c|}{ (Fisher's exact) } & $0.001^{\mathrm{a}}$ \\
\hline Mouthwash & 1 & 11 & 3 & & & \\
\hline Brushing + mouthwash & 0 & 3 & 3 & & & \\
\hline
\end{tabular}


Table 7 (Continued)

\begin{tabular}{|c|c|c|c|c|c|c|}
\hline \multicolumn{7}{|l|}{$n=62$} \\
\hline \multirow[t]{2}{*}{ Variables } & \multicolumn{3}{|c|}{ Frequency } & \multirow[t]{2}{*}{$\chi^{2}$} & \multirow[t]{2}{*}{ df } & \multirow[t]{2}{*}{$p$-Value } \\
\hline & Poor & Good & Very good & & & \\
\hline \multicolumn{7}{|c|}{ Presence of sore mouth } \\
\hline Yes & 2 & 8 & 2 & 9.133 & 2 & \\
\hline No & 1 & 20 & 29 & \multicolumn{2}{|c|}{ (Fisher's exact) } & $0.013^{\mathrm{b}}$ \\
\hline \multicolumn{7}{|l|}{ Tumor type } \\
\hline Head and neck & 3 & 18 & 2 & 28.196 & 10 & \\
\hline Respiratory & 0 & 0 & 3 & \multicolumn{2}{|c|}{ (Fisher's exact) } & $0.001^{\mathrm{a}}$ \\
\hline Gastrointestinal & 0 & 3 & 6 & & & \\
\hline Reproductive & 0 & 5 & 14 & & & \\
\hline Genitourinary & 0 & 0 & 2 & & & \\
\hline Hematology & 0 & 2 & 4 & & & \\
\hline \multicolumn{7}{|l|}{ Staging of cancer } \\
\hline I & 0 & 1 & 0 & 1.751 & 6 & \\
\hline II & 2 & 15 & 16 & \multicolumn{2}{|c|}{ (Fisher's exact) } & 0.988 \\
\hline III & 1 & 10 & 12 & & & \\
\hline IV & 0 & 2 & 3 & & & \\
\hline \multicolumn{7}{|l|}{ Presence of metastasis } \\
\hline Yes & 0 & 7 & 16 & 6.324 & 2 & \\
\hline No & 3 & 3 & 21 & \multicolumn{2}{|c|}{ (Fisher's exact) } & 0.055 \\
\hline
\end{tabular}

Indicates highly significant.

bIndicates significant.

Data presented in this table reveal that the $p$-value computed between TAs and oral care $(p=0.001)$, tumor type $(p=$ 0.001 ) is $<0.05$, which is highly significant. Hence we accept the research hypothesis with regards to these two variables and conclude that there is significant association with selected demographic variable and TAs (-Table 8).

\section{Discussion}

In the present study $64.5 \%$ of the patients were female and $35.5 \%$ were male and belonged to the age group of 20 to 65 years. Out of the 62 patients, 93.5\% were using chemotherapy drugs. When compared with the severity of cancer, $53.3 \%$ of the patients had stage II cancer and $37.1 \%$ had stage III cancer. Metastasis was noted among $62.9 \%$ of subjects. In this study QOL among cancer patients was assessed using QOL grade. Fifty percent patients reported very good QOL, $45.2 \%$ reported good QOL, and $4.8 \%$ reported poor QOL.

An exploratory survey was conducted among 768 cancer patients, older than 30 years, from selected reputed cancer hospitals in Karnataka who were diagnosed with 3rd and 4th stages of cancer in head and neck, breast, cervix, gastrointestinal tract, and lung, and colorectal cancer, and had undergone chemotherapy, surgery, radiotherapy, or a combination of them. The result shows that QOL of majority of patients was influenced by their symptoms. Out of 768 cancer patients $82.3 \%$ showed low QOL scores.7
In the present study, $p$-value computed between the QOL and oral care $(p=0.001)$, sore mouth $(p=0.013)$, and tumor type ( $p=0.001)$ is $<0.05$. Hence we accept the research hypothesis with regards to these three areas and conclude that there is significant association with the selected demographic variables and QOL.

An analytical cross-sectional study was conducted among 88 women with breast cancer and its association with demographic, social, and clinical data at King Abdullah Medical City, Mecca. The patients had mean global health score of $64.0 \pm 27.7$; the result shows that the most troubling symptoms were insomnia and fatigue, and the most distressing symptom was hair loss. ${ }^{8}$

\section{Conclusion}

Cancer is a group of diseases involving abnormal cell growth, which has a potential to invade or spread to other parts of the body. The symptoms vary according to the type of cancer. The treatment can be done by radiation therapy, chemotherapy, surgeries, or a combination of these. Taste alteration is one of the side effects usually seen in patients with cancer and its treatments. The physical impact of cancer and cancer treatments can also affect the quality of life of patients. This study concludes that there exists a strong negative correlation between taste alterations and quality of life. 
152 Taste Alterations and Quality of Life among Cancer Patients Wilson et al.

Table 8 Association of taste alterations (TAs) and demographic variables

\begin{tabular}{|c|c|c|c|c|c|c|}
\hline \multicolumn{7}{|l|}{$n=62$} \\
\hline \multirow[t]{2}{*}{ Variables } & \multicolumn{3}{|c|}{ Frequency } & \multirow[t]{2}{*}{$\chi^{2}$} & \multirow[t]{2}{*}{ df } & \multirow[t]{2}{*}{$p$-Value } \\
\hline & Mild & Moderate & Severe & & & \\
\hline \multicolumn{7}{|l|}{ Gender } \\
\hline Male & 7 & 5 & 10 & 5.350 & 2 & \\
\hline Female & 25 & 5 & 10 & \multicolumn{2}{|c|}{ (Fisher's exact) } & 0.073 \\
\hline \multicolumn{7}{|l|}{ Marital status } \\
\hline Single & 3 & 0 & 2 & 7.436 & 6 & \\
\hline Married & 27 & 7 & 15 & \multicolumn{2}{|c|}{ (Fisher's exact) } & 0.288 \\
\hline Divorced & 1 & 0 & 1 & & & \\
\hline Widowed & 1 & 3 & 2 & & & \\
\hline \multicolumn{7}{|l|}{ Diagnosed with another disease } \\
\hline Yes & 3 & 0 & 2 & 1.052 & 2 & \\
\hline No & 29 & 10 & 18 & \multicolumn{2}{|c|}{ (Fisher's exact) } & 0.847 \\
\hline \multicolumn{7}{|c|}{ Receiving drugs other than chemotherapy } \\
\hline Yes & 2 & 0 & 2 & 1.109 & 2 & \\
\hline No & 30 & 10 & 18 & \multicolumn{2}{|c|}{ (Fisher's exact) } & 0.644 \\
\hline \multicolumn{7}{|l|}{ Method of oral care } \\
\hline Brushing teeth & 23 & 3 & 2 & 29.755 & 6 & \\
\hline Rinsing mouth with water & 3 & 2 & 8 & \multicolumn{2}{|c|}{ (Fisher's exact) } & $0.001^{\mathrm{a}}$ \\
\hline Mouthwash & 2 & 3 & 10 & & & \\
\hline Brushing + mouthwash & 4 & 2 & 0 & & & \\
\hline \multicolumn{7}{|l|}{ Presence of sore mouth } \\
\hline Yes & 4 & 3 & 5 & 2.098 & 2 & \\
\hline No & 28 & 7 & 15 & \multicolumn{2}{|c|}{ (Fisher's exact) } & 0.343 \\
\hline \multicolumn{7}{|l|}{ Tumor type } \\
\hline Head and neck & 0 & 6 & 17 & 45.225 & 10 & \\
\hline Respiratory & 3 & 0 & 0 & \multicolumn{2}{|c|}{ (Fisher's exact) } & $0.001^{\mathrm{a}}$ \\
\hline Gastrointestinal & 5 & 2 & 2 & & & \\
\hline Reproductive & 17 & 2 & 0 & & & \\
\hline Genitourinary & 2 & 0 & 0 & & & \\
\hline Hematology & 5 & 0 & 1 & & & \\
\hline \multicolumn{7}{|l|}{ Staging of cancer } \\
\hline I & 0 & 1 & 0 & 8.737 & 6 & \\
\hline II & 15 & 7 & 11 & \multicolumn{2}{|c|}{ (Fisher’s exact) } & 0.222 \\
\hline III & 14 & 1 & 8 & & & \\
\hline IV & 3 & 1 & 1 & & & \\
\hline \multicolumn{7}{|l|}{ Presence of metastasis } \\
\hline Yes & 16 & 3 & 4 & 5.004 & 2 & \\
\hline No & 16 & 7 & 16 & \multicolumn{2}{|c|}{ (Fisher's exact) } & 0.074 \\
\hline
\end{tabular}

Indicates highly significant. 


\section{Funding}

The authors thank Rajiv Gandhi University of Health Sciences, Bengaluru, Karnataka, India, for providing the financial support.

\section{Conflict of Interest}

None declared.

\section{Acknowledgments}

The authors would like to acknowledge the support received from administrative and teaching faculty of Father Muller College of Nursing, Mangaluru, Karnataka, India, and all the participants of the study.

\section{References}

1 India Against Cancer. National Institute of Cancer Prevention and Research Cancer statistics. http://cancerindia.org.in/cancerstatistics/. Accessed February 26, 2019

2 Mayo Foundation for Medical Education and Research. Symptoms and causes Mayo Clinic. https://www.mayoclinic.org/diseasesconditions/cancer/symptomscauses/ syc20370588. Accessed February 22, 2019

3 The American Cancer Society. How is chemotherapy used to treat cancer. https://www.cancer.org/treatment/ treatments-andside-effects/treatment-types/chemotherapy/how-is-chemotherapy-used-to-treatcancer.html. Accessed February 22, 2019

4 Cancer Council Victoria. Physical effects of cancer. https:// www.cancervic.org.au/living-with-cancer/emotions/ ccv-physical-effects.html. Accessed February 28, 2019

5 Bomford CK, Kunkler IH, Walter and Miller's Textbook of Radiotherapy: Radiation Physics, Therapy and Oncology. London, UK: Churchill Livingstone; 2002 e

6 Murtaza B, Hichami A, Khan SA, Ghiringhelli F, Khan AN. Alteration in taste perception in cancer: causes and strategies of treatment. Front Physiol. https://www.frontiersin.org/ articles/10.3389/fphys.2017.00134/full. Accessed February 24, 2019

7 Heydarnejad MS, Hassanpour DA, Solati DK. Factors affecting quality of life in cancer patients undergoing chemotherapy. Afr Health Sci 2011;11(2):266-270

8 García-Chías B, Figuero E, Castelo-Fernández B, CebriánCarretero JL, Cerero-Lapiedra R. Prevalence of oral side effects of chemotherapy and its relationship with periodontal risk: a cross-sectional study. Support Care Cancer. https:// link.springer.com/article/10.1007\%2Fs00520-019-4650-6. Accessed Febuary 19, 2019 